TAO, Vol.3, No.3, 293-304, September 1992

\title{
On the Characteristics of Bottom Tidal Currents in Northeast Taiwan
}

\author{
CHONG-KUNG WU*
}

(Received: January 6, 1992; Revised: August 10, 1992)

\begin{abstract}
A self-recording current metering subsurface mooring was deployed on the slope where the water depth is $270 \mathrm{~m}$, about 14 nautical miles SSE from the Peng-Chia-Yu islet northeast of Taiwan. Data shows that bottom tidal motions are very strong, and their periodicities are diurnal, semidiurnal and fourth diurnal. Semidiurnal tidal motions have the most energy, and act as the major component in the observed current field. Tidal current progressive vector diagram shows that the principal axis of current ellipse points NW-SE. Due to interaction with the sea floor, onshore tidal motions impinging on a sloping continental shelf will acquire a vertical motion which may contribute to the local upwelling.
\end{abstract}

\section{INTRODUCTION}

The Kuroshio coming from the Phillippine Sea flows mainly along the eastern coast of Taiwan toward the north. As the Kuroshio approaches the sharply curved continental shelf edge, it moves northeastward. Figure 1, after Sun (1987), shows the yearly mean (upper left panel) and seasonal averages (lower right panel) of the surface axial path of the Kuroshio in the vicinity of Taiwan based on 25 years (1953-1977) of GEK data. On the average, the Kuroshio axis moves shoreward in fall and winter, and seaward in spring and summer, in agreement with observations in 1966-1967 (Nitani, 1972) and in 1974-1975 (Chu, 1976). Wang (1987) and Song (1987) show the near-surface salinity fields over the East China Sea in winter (December 1984-January 1985) and summer (June-July 1984). There is a $\Gamma$ shape salinity front in winter and a $\Omega$ shape salinity front in summer. Chao (1991) pointed out that the primary influence of the Kuroshio on the circulation of the East China Sea comes from the region northeast of Taiwan, where the sudden expansion of shelf width causes the isobaths of the continental slope to become more zonal, almost perpendicular to the axis of the Kuroshio to the east of Taiwan. The bulk of the northward flowing left-bounded Kuroshio at depths is expected to follow isobaths northeastward to conserve potential vorticity. However, surface and subsurface Kuroshio water may overshoot and spill over the continental shelf. Conceivably, the intrusion of Kuroshio water onto the shelf generates upwelling and

* Department of Marine Resources, National Sun Yat-Sen University, Kaoshiung, Taiwan, R.O.C. 


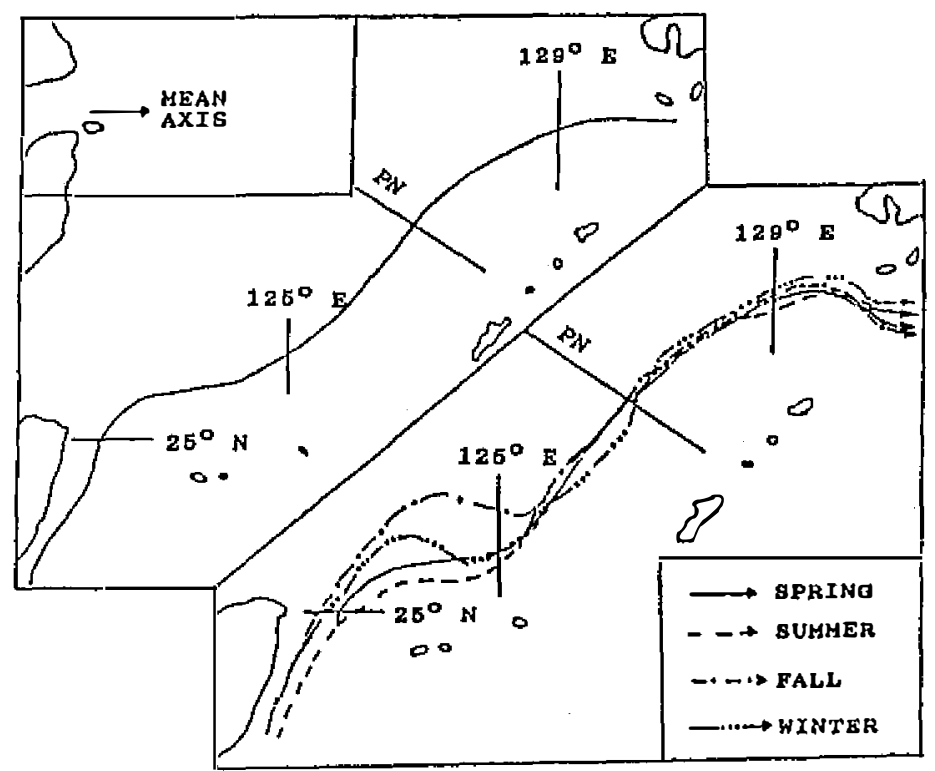

Fig. 1. The Kuroshio paths defined by the axes of surface current speed along the continental margin of the East China Sea based on 25 years of GEK data (after Sun, 1987). The yearly mean and seasonal means are shown on the upper left and lower right panels, respectively.

anticyclonic circulation, and $\Gamma$ shape of the Kuroshio water in the East China Sea in winter can be largely attributed to the shoreward surface Ekman drift associated with the northerly wind. Chuang and Wu (1991) showed that in winter 1990, in the outer shelf region, across a canyon northeast of Taiwan, existed a steady subsurface flow in the southward, along-slope direction, opposite to the nearby northward flowing Kuroshio current. Tides nun transverse to the mean flow. Subtidal current fluctuations were concentrated in the synoptic (2-4 days) band.

There exists a quasi-permanent upwelling center of Kuroshio subsurface water above the shelf break at the northeast offshore area of Taiwan, based on the hydrographic surveys and NOAA-HRPT SST image pictures (Yin, 1973; Uda and Kishi, 1974; Fan, 1980; Chem and Wang, 1989; Chem et al., 1990; Wong et al., 1991; Hsu, 1991a,b). Yin (1973) pointed out that the cold water mass near N.N.E. of Taiwan is a mixing of intermediate water mass, Kuroshio water mass and coastal water mass, and the upwelling of the cold water is induced by wind, current and bottom topography. Since then, the causes of this cold dome were suggested as having many different factors, for example, 1) topographic upwelling (Yin, 1973; Fan, 1980; Chem and Wang, 1989; Wong et al., 1991; Rou and Chen, 1991), 2) thermal wind effect (Chem and Wang, 1990a), 3) oceanic front (Liu and Pai, 1987; Liu et al., 1988), 4) internal tide (Chem and Wang, 1990b).

Nakamura et al. (1990) discussed the characteristics of oceanic fronts in the East China Sea from the viewpoint of oceanic currents. They found that variations in time scale of a few hours around Kuroshio Branch were connected with tidal current in the south of the East China Sea. In this paper, we present the evidence of bottom tidal motion, internal tide and 
upwelled subsurface Kuroshio water. We discuss interaction of the semidiumal bottom tidal current with sea floor and its relationship with cold dome at the shelf margin in the vicinity of the Peng-Chia-Yu islet northeast of Taiwan. Our results are consistent with finding of Nakamura et al. (1990).

\section{OBSERVATIONS}

Self-recording current meters (AANDERAA RCM-7s and/or RCM-4s) were deployed at station W (Figure 2) on the continental slope, 14 nautical miles SSE from the Peng-Chia-Yu islet, by using a subsurface mooring buoy system during the winter of 1990 and the spring of 1991 . The location of station $\mathrm{W}$ is at $25^{\circ} 25.4^{\prime} \mathrm{N}, 122^{\circ} 7.5^{\prime} \mathrm{E}$ with bottom depth around $270 \mathrm{~m}$. In this area, a quasi-permanent cold dome on the shelf had been well-documented.

Hereafter we name observation periods from Nov.3-Nov.8 1990 as leg 1, and from Mar. 4-Apr. 21, 1991 as leg 2 respectively. The instrument and bottom depth is $230 \mathrm{~m} / 263 \mathrm{~m}$ for $\operatorname{leg} 1$, and $245 \mathrm{~m} / 270 \mathrm{~m}$ for leg 2 .

Sampling interval for the RCMs was set at 10 minutes before deploying. After retrieving the RCMs, data was carefully edited, and then standardized to one hour sampling records by further vector averaging.

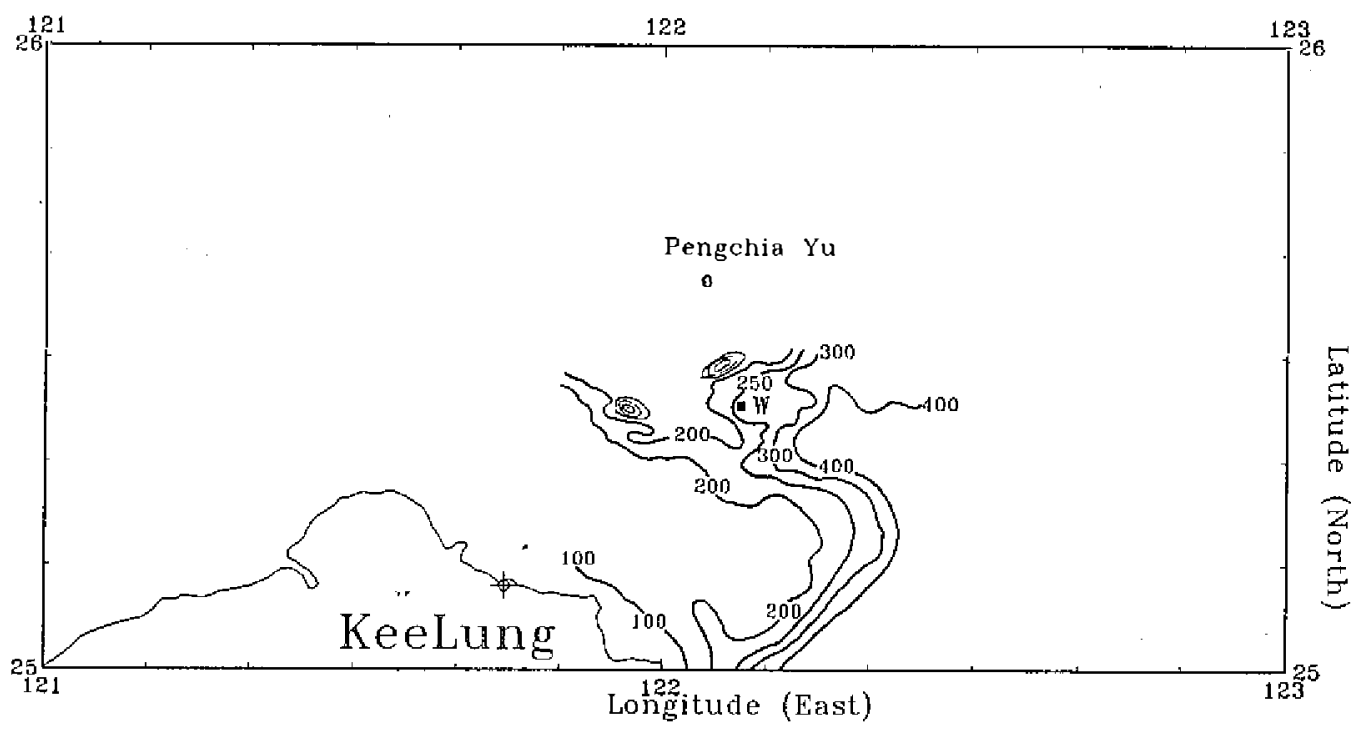

Fig. 2. Map of the area northeast of Taiwan, depth in meters. Location of station W denoted by solid square where water depth is around $270 \mathrm{~m}$.

\section{RESULTS}

The hourly records of temperature, north (V) and east (U) components of velocity were used to analyze power spectra and tidal current progressive vector diagram (PVD). Figure 3 shows the energy power spectra in which bottom tidal motions are evident. Their periodicities are diumal, semidiumal and fourth diumal. The semidiumal tidal motions have a very strong energy peak, and more energy than others. Semidiumal tidal motions are also evident in the 


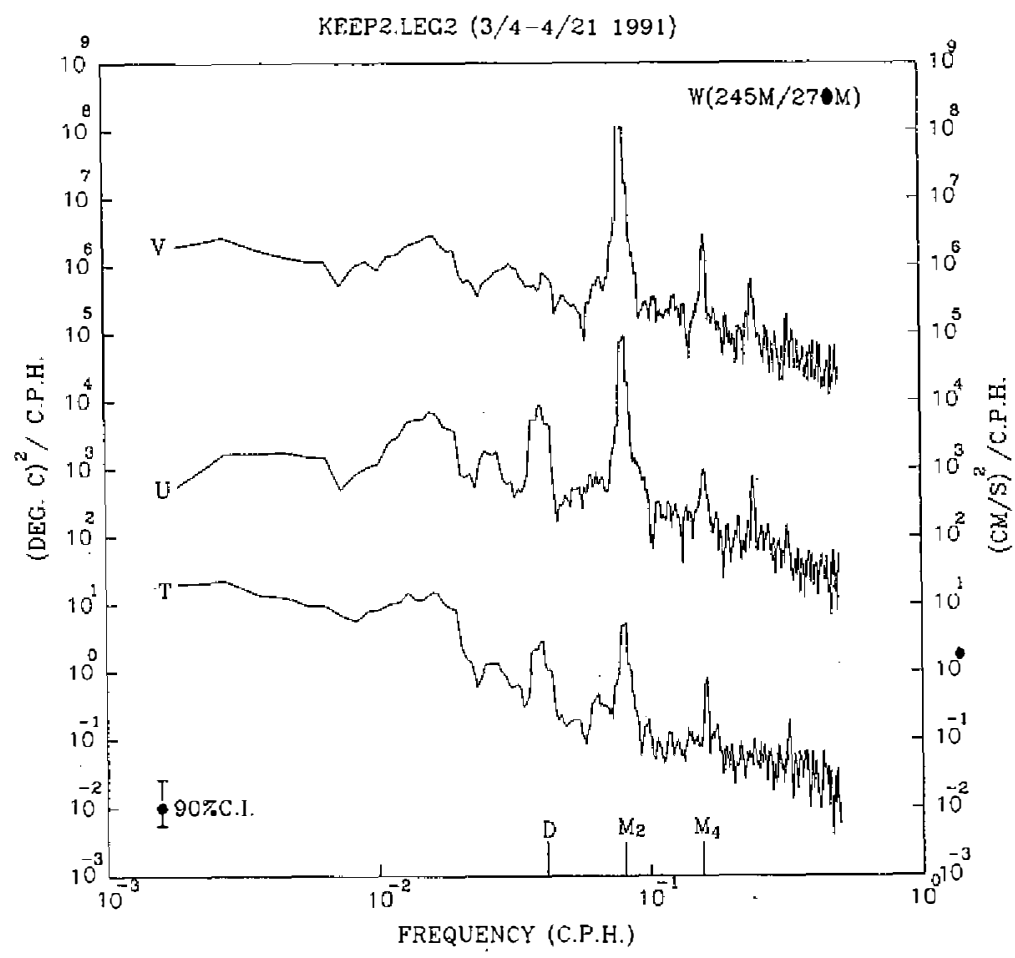

Fig. 3. Energy power spectra of north (V), east (E) component of velocity and temperature $(\mathrm{T})$, where $\mathrm{V}$ component has been upper lifted three orders. Sticks D, M2 and M4 denote the frequencies of diurnal, semidiurnal and fourth diurnal respectively. $\$$ denotes $90 \%$ confidence interval based on 10 degrees of freedom.

PVD (Figures 4 and 5). The direction of principal axis of current ellipse is NW-SE. Its principal axis is about $4-5$ nautical miles long.

Figures 6 and 7 show the ten minute records of temperature (upper panel), current direction (middle panel) and current speed (lower panel). Current speeds change regularly from peak to trough in about 3 hours. Similarly, current directions change regularly from the NW direction to the SE direction in about 6 hours. This indicates semidiumal tidal motions are dominant in the current field. Temperatures also vary regularly from peak to trough in about 6 hours, accompanied with the change of current directions. When currents are in the NW direction (onshore), water temperature decreases continously for about 3 hours. Then currents in the SE direction (offshore), and water temperature increases continously for about 3 hours.

Besides the regular variations mentioned above, there are small random variations in velocity and temperature records (Figures 6 and 7). These random variations may be due to high frequency internal waves. For the description of subtidal low frequency variation in the observed current field, we refer readers to the paper of Chuang and Wu (1991). 
Fig. 4. Hourly tidal current progressive vector diagram stars from Nov. 4 to Nov. 51990 at station W. Instrument/bottom depth is $230 \mathrm{~m} / 263 \mathrm{~m}$. Principal axis of current ellipse points NW-SE direction, and its principal axis is about 4 nautical miles long.

Fig. 5. Hourly tidal current progressive vector diagram stars from Apr. 16 to Apr. 181991 at station W. Instrument/bottom depth is $245 \mathrm{~m} / 270 \mathrm{~m}$. Principal axis of current ellipse points NW-SE direction, and its principal axis is about 5 nautical miles long.
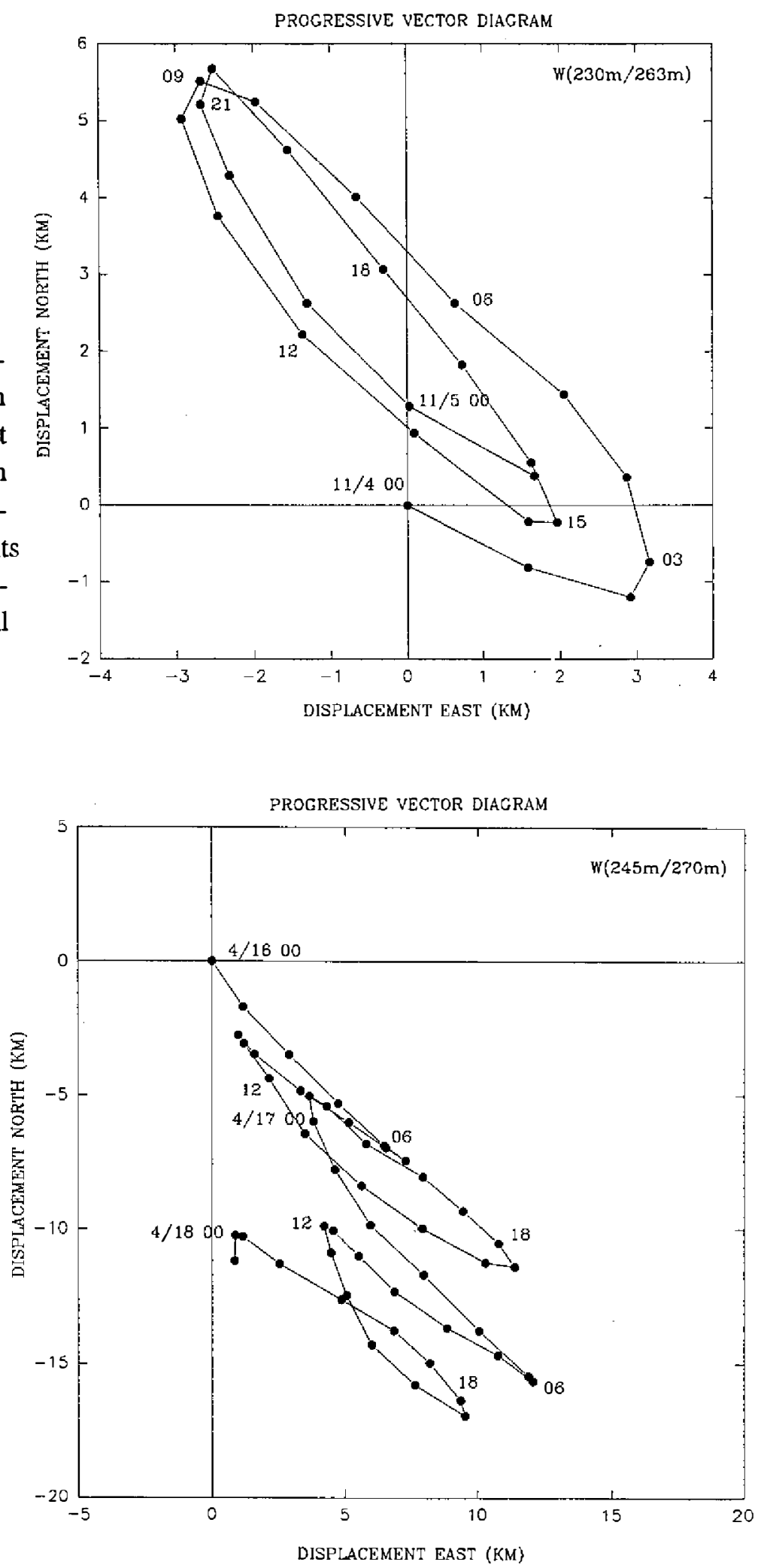
Fig. 6. Ten minutes sampling interval records of temperature, current direction and current speed at station W during leg 1.

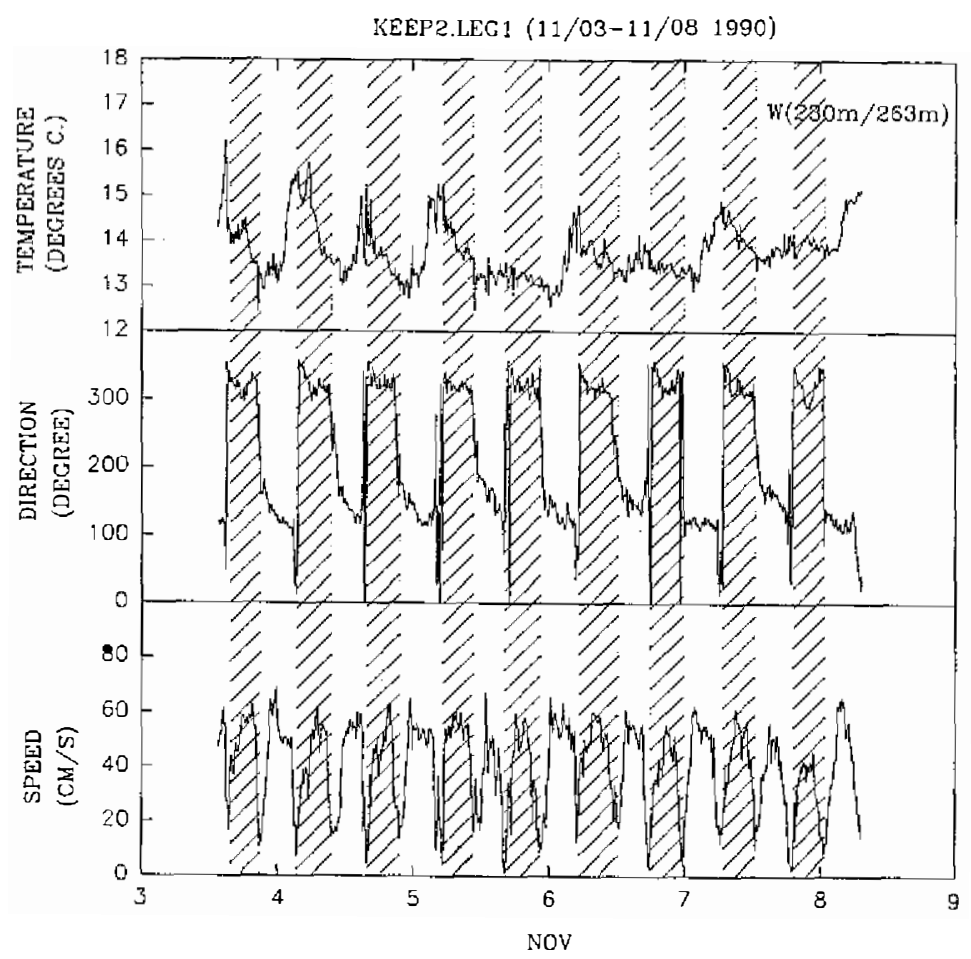

Fig. 7. Ten minutes sampling interval records of temperature, current direction and current speed at station $\mathrm{W}$ during leg 2.

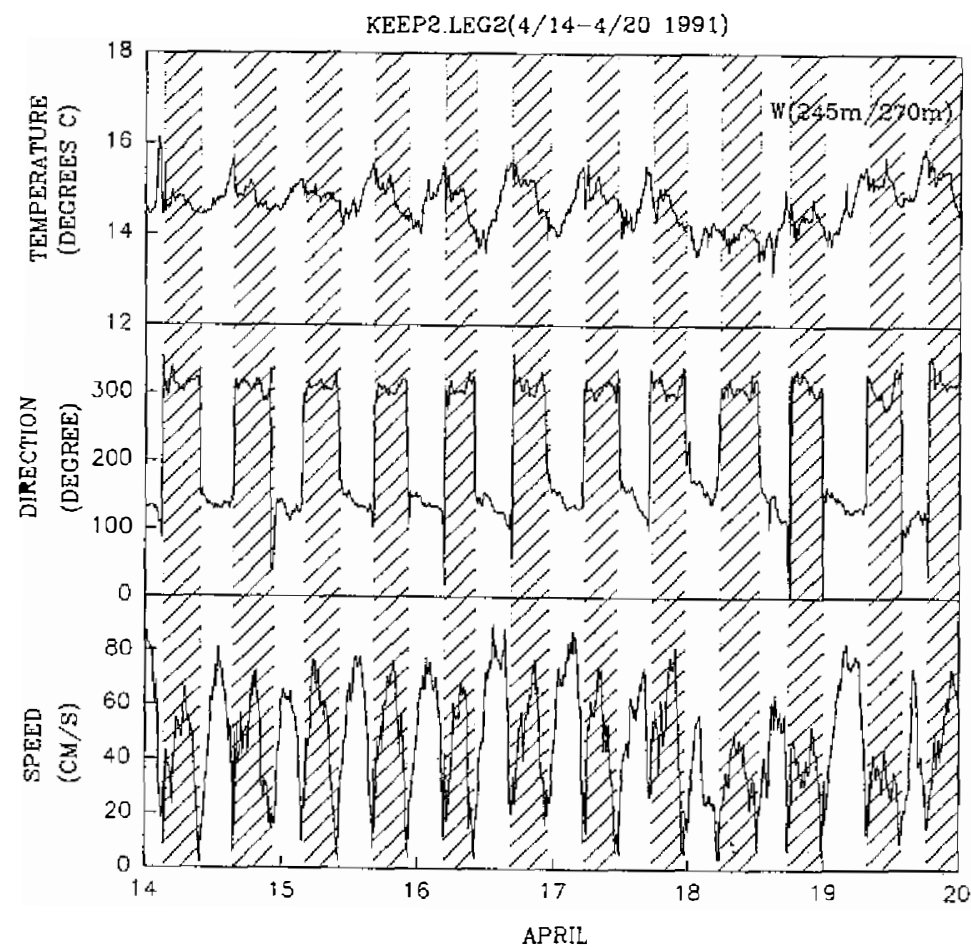




\section{DISCUSSION}

Figure 8 shows T-S diagram from CTD data at the mooring station W during leg 1 (Nov. 3) and leg 2 (Apr. 5). The water type of the whole water column is mostly the upwelled subsurface Kuroshio water (see Chern et al., 1990). Wong et al. (1991) studied the hydrographic data across the frontal region between the East China Sea and the Olinawa Trough northeast of Taiwan, and concluded that the topographically-induced upwelling water was the modified Kuroshio water from about $300 \mathrm{~m}$ deep. Its composition seems to remain rather constant with time with a temperature and salinity of around $13^{\circ} \mathrm{C}$ and 34.4 psu respectively. Nakamura et al. (1990) used the hydrographic surrey in the south East China Sea and showed that on the bottom layer, the shelf warm water of more than $16^{\circ} \mathrm{C}$ is replaced by less than $16^{\circ} \mathrm{C}$ water about every 6 hours, corresponding to semidiumal tidal period. They concluded that this less than $16^{\circ} \mathrm{C}$ water is due to the advection of intermediate water of the Kuroshio to the bottom layer on the shelf. The range of temperature fluctuations in Figures 6 and 7 is between $16.2^{\circ} \mathrm{C}-12.4^{\circ} \mathrm{C}$ and $16.1^{\circ} \mathrm{C}-13.1^{\circ} \mathrm{C}$ respectively. This indicates the cold water accompanied with onshore tidal motions $(\mathrm{NW})$ at the mooring station $\mathrm{W}$, is associated with the advection of intermediate water of the Kuroshio.

Tang (1991) showed the presence of internal tide with amplitude as large as $30 \mathrm{~m}$ on the thermocline from CTD data at the anchor station 5320, about 9 nautical miles NW from the mooring station $\mathrm{W}$ during the cruise \#280 of the RV OCEAN RESEARCHER 1 . Figures 9 and 10 show internal tide with an amplitude as large as $90 \mathrm{~m}$ (see $15^{\circ} \mathrm{C}$ and 34.6 psu contour), from CTD data at the anchor station at $25^{\circ} 25^{\prime} \mathrm{N}, 122^{\circ} 15^{\prime} \mathrm{E}$ about 7.5 nautical miles east from the mooring station $\mathrm{W}$ during the cruise \#271 of the R/N OCEAN RESEARCHER 1. Therefore internal tides are very common phenomenon in the vicinity of the Peng-Chia-Yu islet northeast of Taiwan. This is consistent with Maeda's finding (1979) that internal tide is dominant around the area of south East China Sea.

Fig. 8. T-S diagram from CTD data at the mooring station $\mathrm{W}$ during leg 1 (Nov. 3 1990) and leg 2 (Apr. 5 1991)

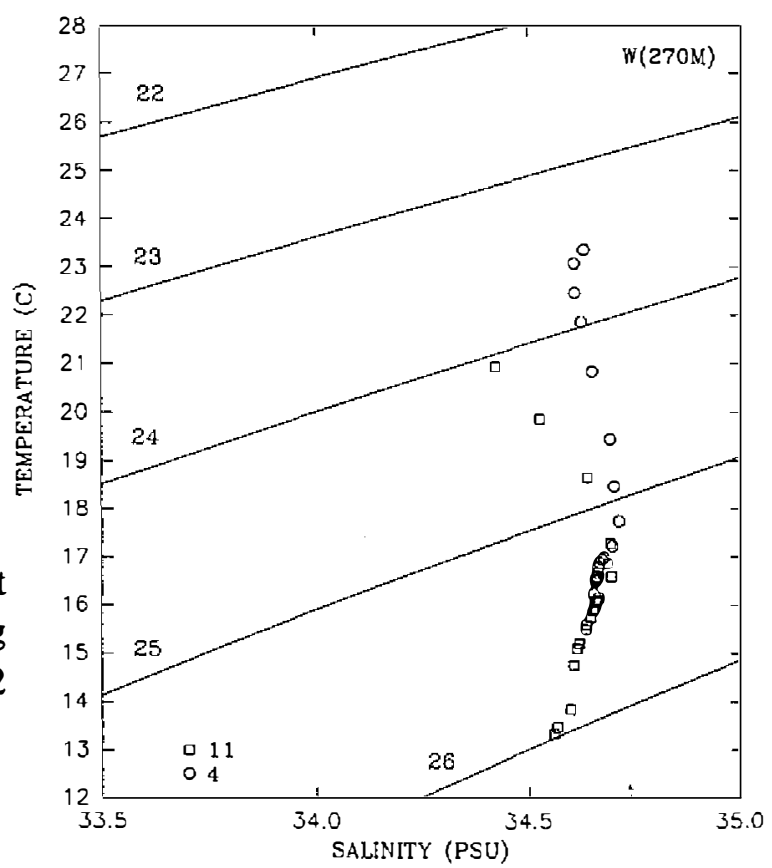


Fig. 9. Isopleth of temperature at the anchor station $25^{\circ} 25^{\prime} \mathrm{N}$, $122^{\circ} 15^{\prime} \mathrm{E}$ about 7.5 nautical miles east from the mooring station $\mathrm{W}$. Time axis denotes hourly interval, started from 12:30 p.m. March 8 to $04: 30$ a.m. March 91991.
Fig. 10. Isopleth of salinity at the anchor station $25^{\circ} 25^{\prime} \mathrm{N}$, $122^{\circ} 15^{\prime} \mathrm{E}$ about 7.5 nautical miles east from the mooring station $\mathrm{W}$. Time axis denotes hourly interval, started from 12:30 p.m. March 8 to $04: 30$ a.m. March 91991.
TEMPERATURE CONTOLR

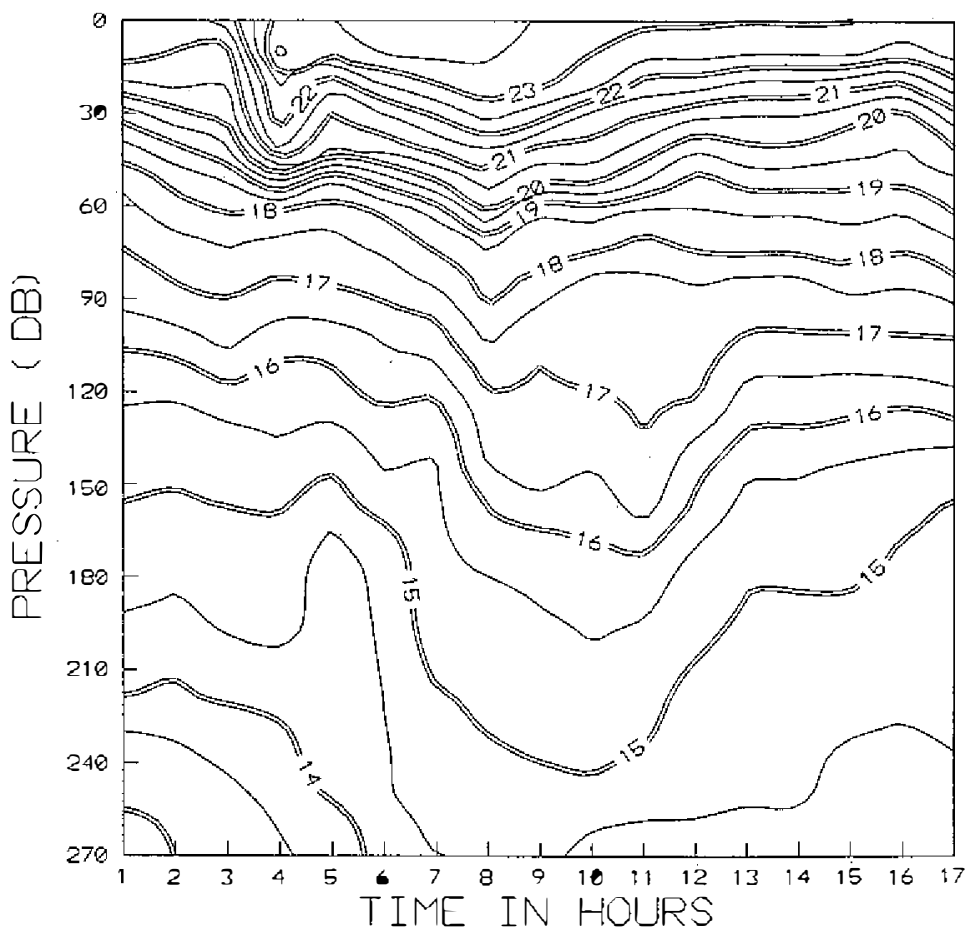

SALINITY CONTOUR

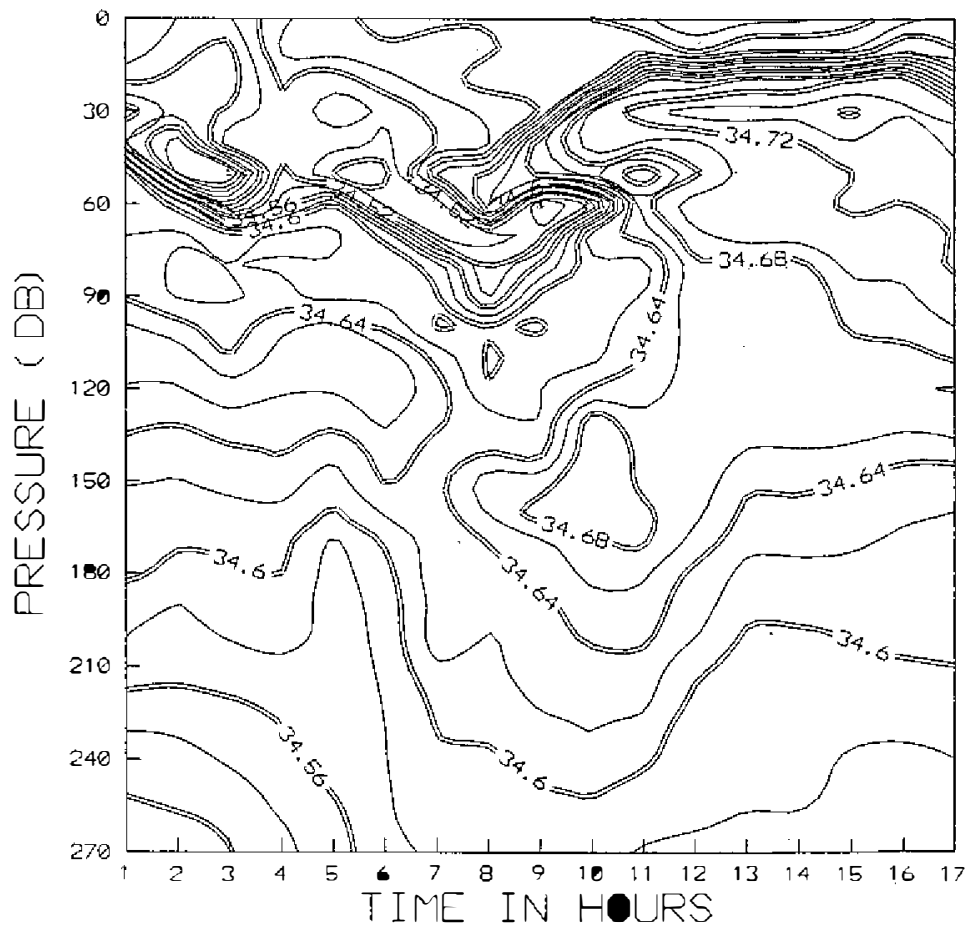


Nakamura et al. (1990) found that the semidiumal current is prevailing and the direction of principal axis of current ellipse (NW-SE) is almost perpendicular to the Kuroshio axis (NE). The semidiumal fluctuation is also present in the temperature field, indicating the existence of internal tide. When tidal current is strong, the intrusion of the intermediate water of the Kuroshio system is accompanied with tidal excursion through the bottom layer of the continental shelf. As a result, the geographical location of oceanic front and horizontal gradient of water temperature changed. Our study is consistent with Nakamura's finding, namely, when prevailing onshore semidiumal current is NW, the Kuroshio intermediate water moves onto shelf in the bottom layer on the continental shelf.

\section{CONCLUSION}

We have presented the evidence of bottom tidal motion, internal tide and upwelled subsurface Kuroshio water. Due to interaction with the sea floor, onshore tidal motions impinging on a sloping continental shelf will acquire a vertical motion (Pond and Pickard, 1983) which may contribute to the local upwelling.

Acknowledgements This work was sponsored by the National Science Council under the contract No. NSC80-0209-M110-01. Critical comments by the reviewers are appreciated. We acknowledge the cooperation of the crew and technical staff of the R/ Ocean Researcher I during our cruises. We are especially grateful for the assistance of H.H. Lee and C.Y. Huang.

\section{REFERENCES}

Chao, S. Y., 1991: Circulation of the East China Sea, A Numerical Study. Horn Point Environmental Laboratories, University of Maryland, U.S.A.

Chern, C. S. and J. Wang, 1989: On the water masses at northern offshore area of Taiwan, Acta Oceanographica Taiwanica, 22, 14-32.

Chern, C. S and J. Wang, 1990a: On the Kuroshio Branch Current north of Taiwan, Acta Oceanographica Taiwanica, 25, 55-64.

Chern, C. S. and J. Wang, 1990b: On the Mixing of Waters at a Northern Offshore Area of Taiwan. TAO, 1, 297-306.

Chem, C. S, J. Wang and D. P. Wang, 1990: The Exchange of Kuroshio and East China Sea Shelf Water, J. Geophys. Res., 95, 16017-16023.

Chu, T. Y. 1976: Study of the Kuroshio current between Taiwan and Ishigakijima, Acta Oceanographica Taiwanica, 6, 1-24.

Chuang, W. S. and C. K. Wu, 1991: Slope Current Fluctuations Northeast of Taiwan, Winter 1990, Journal of the Oceanographical Society of Japan, 47, 185-193.

Fan, K. L., 1980: On upwelling off northeastem shore of Taiwan, Acta Oceanographica Taiwanica, 11, 105-117.

Hsu, C. L., 1991a: Surface flow pattern study northeast Taiwan from the viewpoint of NOAA-HRPT SST images. KEEP \& WOCE Conference March, 1991, in Chinese.

Hsu, C. L., 1991b: NOAA-HRPT SST image pictures during KEEP hydrography cruises from Aug. 1990-July 1991. KEEP Newsletter No. 8, in Chinese. 
Liu, C. T. and S. C. Pai, 1987: As the Kuroshio turns: (II) The oceanic front north of Taiwan, Acta Oceanographica Taiwanica, 18, 49-61.

Liu, K. K., S. C. Pai, and C. T. Liu, 1988: Temperature- nutrient relationships in the Kuroshio and adjacent waters near Taiwan, Acta Oceanographica Taiwanica, 21, 1-17.

Maeda, A., 1979: Short intemal waves on the margin of the continental shelf of the East China Sea. La mer, 17, 18-27.

Nakamura, Y., K. Miyaji, K. Tamai and Y. Zheng, 1990: On the Characteristics of Oceanic Front in the East China Sea from the Viewpoint of Oceanic Currents. Proceedings of Japan-China Joint Symposium of the Cooperative Study on the Kuroshio November 1416, 1989, Tokyo, Japan. Japan-China Joint Research Programme on the Kuroshio.

Nitani, H., 1972: Beginning of the Kuroshio, Kuroshio, Physical Aspects of the Japan Current, H. Stommel and K. Yoshida, Eds., Univ. of Washington Press, 129-156.

Pond, S. and G. L. Pickard, 1983: Introductory Dynamical Oceanography, 2nd edition. Pergamon Press Inc., New York, 329pp.

Rou, R. and C. T. Chen, 1991: Descriptive Chemical Oceanography off Northeast Taiwan: The Comparisons Between Summer and Winter, Oceanic Technology Society, No. 9, in Chinese with English abstract.

Song, W., 1987: Physical oceanographic features in the Kuroshio mainstream and its adjacent area in the East China Sea during June to July 1984 (in Chinese with English abstract), Essays on the Investigation of Kuroshio, X. Sun, Ed., Ocean Press, Beijing, 99-117.

Sun, X. 1987: Analysis of the surface path of the Kuroshio in the East China Sea (in Chinese with English abstract), Essays on the Investigation of Kuroshio, X. Sun, Ed., Ocean Press, Beijing, 1-14.

Tang, C. Y., 1991: R/V Ocean Researcher 1 cruise \#280 report, KEEP LETTER No. 8, in Chinese.

Uda, M. and A. Kishi, 1974: Clyclonic cold eddies along the edge of the Kuroshio current in relation to the genesis and passage of cyclones, I. Waters north of Taiwan, The Kuroshio III, Proceedings of the 3rd Symposium, Bangkok, Thailand, 1972, 199-218.

Wang, Y., 1987: Physical oceanographic features in the Kuroshio mainstream and its adjacent area in the East China Sea during December 1984 to January 1985 (in Chinese with English abstract), Essays on the Investigation of Kuroshio, X. Sun, Ed., Ocean Press Beijing, 133-148.

Wong, G. T. F., S. C. Pai, K. K. Liu, C. T. Liu and C. T. A. Chen, 1991: Variability of the Chemical Hydrography at the Frontal Region between the East China Sea and the Kuroshio North-east of Taiwan. Estuarine, Coastal and Shelf Science, 33, 105-120.

Yin, F., 1973: Preliminary study of cold water mass near N.N.E. of Taiwan. Acta Oceanographica Taiwanica, 3, 157-180. 


\title{
台灣東北海域底潮流特性
}

\author{
吴重坤 \\ 國立中山大學海洋資源學系
}

\section{摘要}

台湀束北彭佳嶼南南束方約 14 海浬, 水深 $270 \mathrm{M}$ 處錨定 一组海流儀。資料顯示底潮流非常強勁, 計有 $1 / 4$ 日潮、半日 潮及全日潮; 其中以半日潮能量最智著, 爲該區海域流場的主要 成分之一。半日底潮流以西北和束南雨個方向爲主。由於受到該 區海底地形的影響, 當潮流往西北方時, 底層的海水會遇淺而爬 升，因而會造成該觀測站西北方陸棚底層水受到來自陸坡方向的 黑潮次層水有規律的入侵。 
